\title{
Study on Adaptation of Soybean under The Coconut
}

\author{
August Polakitan ${ }^{1, *}$, and Conny N Manoppo ${ }^{1}$ \\ ${ }^{1}$ BPTP Sulut- jln Kalasey Sulut Agricultural Campus
}

\begin{abstract}
Problem is that the sunlight passing through the coconut canopy is limited for photosynthesis. The purpose of this study was to measure the performance of the Anjasmoro variety technology package among coconuts. This research was conducted in North Minahasa in 2018. Field trials to test soybeans under the shade of coconut and without shade. Each treatment was repeated at 15 blocks. Technology Package The technology tested included soybean seeds planted at $15 \times 40 \mathrm{~cm}$ spacing. Basic fertilization is applied $50 \mathrm{~kg}$ urea, $75 \mathrm{~kg} \mathrm{SP} 36$ and $150 \mathrm{KCL} /$ ha. Pest or disease control follows the concept of integrated pest control. The data collected included agronomic performance and yield. The collected data were statistically tested using $\mathrm{T}$ (test). The results of the analysis showed that the plant height of $70.6 \mathrm{~cm}$ Anjasmoro variety was not significant with soybeans planted on land without shade. But the number of branches (2.1) was significantly lower than the soybean without shade. The number of soybean pods under the shade of 32 pods of coconut was lower and significantly different from the soybean without shade. The soybean yield among the coconuts was $900 \mathrm{~kg} / \mathrm{ha}$ lower than the soybean without shade, $1,315 \mathrm{~kg} / \mathrm{ha}$.
\end{abstract}

\section{Introduction}

The income of coconut farmers from copra processing is low so that only farmers who have large coconut plantations can depend on this plant for their livelihoods [23]. The productivity of coconut plantations in North Sulawesi is low, because it is more than 50 years after planting. The existing coconut variety is deep coconut. The performance of this coconut plant has grown tall so that as a result the light penetrates the coconut canopy and reaches the land beneath which the coconut is quite large.

The distribution of sunlight that penetrates coconut stands with a spacing of 9x9 m aged 50 years, the light that passes through the coconut canopy is sufficient for the photosynthetic process of soybean plants. The highest solar radiation that reaches the land under the coconut canopy is found when the newly planted coconuts are 1-5 years old. When the coconut is 20 years old, the plants between the coconuts cannot grow normally because of the high level of shade. When the coconut is 50 light years old, it reaches a high enough land so that intercrops can be planted [26]. This is also supported by the distribution of coconut roots only found in an area 2 meters from the base of the coconut tree or about

\footnotetext{
* Corresponding author: polakitan.august4@gmail.com
} 
$25 \%$ of the total land used. This limited root distribution allows the remaining $75-80 \%$ of the land to be cultivated for soybean plants. This is as reported by [26], where the roots used were $25 \%$. The land potential in the people's plantation area is wide enough for mixed farming.

Soybean development under the shade of coconut continues to be studied. This is because soybeans are an important food [25]. One of the strategies to increase soybean production is by utilizing the potential of available land to support increased soybean production, among other things, planting soybeans as an intercropping planted with annual crops including coconut [20].

The problem of developing soybean among coconuts is the low intensity of light and light energy that will be received by shaded plants. Adaptation to shade conditions can be achieved if plants have mechanisms for capturing and using light efficiently. According to [3], soybeans will give a different response to shade conditions. Furthermore, he said that sensitive soybeans will experience a high enough decline in production while tolerant soybeans can still maintain their production even though there is still a decline.

From the results of Asadi's research [1] the reduction in soybean yields in intercropping is $6-52 \%$. Shade stress reaches $50 \%$, so soybean yields decrease by $10-40 \%$ [29]. The results of this study provide opportunities for soybean development among coconuts. Anjasmoro variety with a potential yield of 2.23 tons per ha. Because the decrease in yield due to shade reaches $50 \%$ if soybeans are planted with a potential yield of 2.23 tonnes/ha, farmers still earn 1.1 tonnes per ha among coconuts. This is in accordance with the results of research by [1]. He stated that the Anjasmoro variety of this variety has the potential for production in open land to reach 2.23 tons per ha, the result will decrease 1.72 tons per ha at $25 \%$ shade. If the shade is increased by $50 \%$, the soybean yields decreases by 1.21 tons / ha [1].

Therefore, an effort is needed to test varieties that are adaptive and have optimal yields, especially tolerance to low light intensity in shade, so that later soybean cultivation can be carried out to support soybean production [8]. Anjasmoro varieties are shade tolerant of $30 \%$ and $50 \%$ [18]. The purpose of this study was to test the technological performance and adaptability of Anjasmoro soybeans among specific coconuts for the location of North Minahasa.

\section{Methods}

This research was conducted in Laikit Village, Minahasa Utara district in 2018. The characteristics of the research location can be described as follows: Wet climate conditions for dry land. The study area is in the lowlands. The research used shade from deep coconut plantations aged 40-60 years and without shade. Coconut spacing is 9x9 m. Treatment 1 soybean planted using coconut shade. Treatment 2 soybeans were planted without cover. The soybean tested was Anjasmoro variety and it was repeated in 5 shaded blocks and 5 blocks without shade. The cultivation technique includes Anjasmoro seeds used per ha 40 $\mathrm{kg}$. Seeds are planted 2-3 cm above the land surface or using a planting tool, spacing 10-15 x $40 \mathrm{~cm}, 2-3$ seeds per hole. The number per clump is uniform 2 plants.

Fertilize $50 \mathrm{~kg}$ urea, $75 \mathrm{~kg}$ SP36 and 100-150 KCL / ha at planting time. The first and second fertilization is carried out when weeding is finished, so that the fertilizer is only absorbed by the soybean plants. Pest and disease control is monitored. Control of plant disturbing organisms (OPT) is carried out by monitoring. Pesticides are applied according to the development of the pests and diseases that attack. Data collected included plant height at harvest, number of branches, number of pods and yield per ha. Measurement of plant height is measured using meters. Plant height is measured from the soil surface to the end of the canopy, 10 plants are randomly selected per plot, the height is measured then 
averaged. The number of soybean branches was counted from 10 plants then the results were averaged. The yield per plot is weighed from the yield of 4 x $5 \mathrm{~m}$ tiles. Then averaged. To calculate yield per ha the tile data is converted to ha. Agronomic data and results were analyzed using the $\mathrm{T}$ test.

\section{Results and Discussions}

\subsection{Plant height}

The effect of the interaction between shade and soybean on plant height is presented in Table 1. The results showed that soybean grown among coconuts had an average height of $70.6 \mathrm{~cm}$, but not significantly different than that of soybean in open land. Some research results also suggest that shade causes increased plant height and reduced soybean stem diameter [7, 12, 22, 31, 32]. According to [24], lack of light due to shade changes plant morpho-physiology, such as increasing specific leaf area, stem length and leaf width, but on the other hand decreases stem diameter and total dry matter. [28] stated that up to $75 \%$ shade increased plant height, leaf area, light absorption rate, photosynthesis rate, leaf chlorophyll index, number of filled pods, and seed weight per soybean plant. In general, the rate of increase in plant height was due to the lengthening of the stem segments (etiolation) according to the research of [17]. [14, 30] elongation of stems, petioles, hypocotyl, and apical dominance are forms of avoidance of shade. The avoidance response to shade gives plants the opportunity to get enough sunlight to survive.

Table 1. The soy plant of the Anjasmoro variety in the coconut naungi and is open in northern Minahasa

\begin{tabular}{|l|c|c|}
\hline \multirow{2}{*}{ Description } & \multicolumn{2}{|c|}{ Anjasmoro Variety } \\
\cline { 2 - 3 } & $\begin{array}{c}\text { Among coconuts aged 40-60 } \\
\text { years }\end{array}$ & Open land \\
\hline Height of cm plant & $70.6^{\mathrm{a}}$ & $69^{\mathrm{a}}$ \\
\hline Number of branches & $2.1^{\mathrm{a}}$ & $5.1^{\mathrm{b}}$ \\
\hline Number of pods & $32^{\mathrm{a}}$ & $55^{\mathrm{b}}$ \\
\hline Ton/ha yield & $900^{\mathrm{a}}$ & $1,315^{\mathrm{b}}$ \\
\hline
\end{tabular}

Note: the number followed by the same letter in the same column does not differ manifestly at the 0.05 (T test) test level.

The trend of the soybean plant height under shade was higher than the height of the soybean plant in open land, indicating that the existing shade on coconut trees did not significantly affect the height of the soybean plant. This shows that the sunlight that penetrates the coconut canopy of the soybean plant is able to use the light efficiently so that the height is not significantly different from that in open land.

\subsection{Number of branches}

The results of data analysis in Table 1 show that the number of soybean branches planted between coconuts is lower and significantly different than those planted in open land. In shaded conditions, the light intensity that can be received by plants will be a little so that there is an increase in auxin activity and as a result the cells grow lengthwise. The length of the internode is reflected in the number of branches. The results of research by [19] showed that the level of shade had a significant effect on the number of branches, where the highest number of branches was found in the treatment without shade.

This indicates that soybean grown between coconuts is affected by the existing coconut 
shade. Shaded conditions, soybeans tend to grow vertically to reach sunlight, rather than growing sideways to form new branches. As a result, many plants will collapse because the stems are not strong, so that soybeans can be seen under the shade, creeping and wrapping around other plants. Plant height posture on coconut shade treatment tends to be higher than that without shade. This is due to the interaction between soybean plants and the environment. Shade stress is due to the low light intensity received by soybeans as a result of which plants experience etiolase. The results of research by [12] reports that shade causes an increase in plant height but reduces the diameter of the soybean stem. An increase in plant height as a result of extension of stem internodes [17].

\subsection{Number of Pods}

Soybean pods are zinc for storage of photosynthetic products. The results of the analysis in Table 1. It can be seen that the number of pods planted under the shade of coconut is lower and significantly different compared to soybeans planted in open land. This shows that the soybean under the coconut is only able to form pods $58 \%$ compared to open land. The inability to form pods is thought to be due to insufficient sunlight penetrating the coconut canopy to meet the soybean needs for optimal photosynthesis. The high rate of shedding of flowers and pods was caused by the intense competition for assimilates. [27] reported that the reduction in the number of pod contents was caused by the amount of shedding of flowers and pods reaching 50\%. According to [21], there was a significant positive correlation between seed yield and number of pods. The number of pods is the most important contributor to seed yield [10].

\subsection{Production/Yield}

From the observations in Table 1. It can be seen that the production of soybean under coconut is lower and significantly different than that of soybean grown on open land. This shows that shading and competition factors occur in soybean grown on land between coconuts. Effect of shade and coconut plant competition reduced soybean yield by $41.82 \%$.

This decrease in yield was due to insufficient light transmission reaching the soybean canopy for optimal photosynthesis of soybean plants. As a result, the yield was low. The results of [2] research reported that Anjasmoro variety produced higher plant height and seed weight per plant than Kipas Merah [9]. When compared with Dena 1. It is grown among coconut stands in the yield $0.45-0.91 \mathrm{t} / \mathrm{ha}$, an average of $0.74 \mathrm{t} / \mathrm{ha}$.

Plant competition for light, nutrients can suppress plant yields [4]. Plants that are shaded on several parameters cause a decrease when compared to those without shade because in the shaded condition the plants divide their photosynthate more into the leaves, eventually pod formation decreases [16], as a result the yield of seeds is lower. Research results [11, 15] stated that soybean plants that grow in a shaded environment during the generative phase experience a decrease in photosynthetic activity so that the allocation of photosynthate to the reproductive organs is reduced, which causes the size of the seeds to be smaller than those without shade. Shade causes a reduction in soybean yield and size [13]. According to [6] although the maximum seed size is determined by its genetic potential, soybean seed size can be modified by changes in environmental conditions during the reproductive phase.

The results of the study on the Anjasmoro variety planted on land without shade yields an average yield of $1,315 \mathrm{~kg}$ per ha. The average soybean production under coconut stands is $900 \mathrm{~kg} / \mathrm{ha}$. A simple economic analysis showed that the $\mathrm{B} / \mathrm{C}$ ratio with the highest production $(910 \mathrm{~kg} / \mathrm{ha})$ obtained $\mathrm{B} / \mathrm{C} 1.71$. If from the results of average productivity (740 $\mathrm{kg} / \mathrm{ha}$ ), the $\mathrm{B} / \mathrm{C}$ ratio is around 1.30 [9]. Seeing the yield obtained per ha 1.3 tonnes per ha, 
soybean farming under coconut stands shows that there is hope of increasing the yield of coconut farmers through poly-cultivation of coconut and soybeans.

\section{Conclusion}

The land between the coconuts over 50 years old can be planted with Anjasmoro soybeans. The results of the soybean study showed:

1. Soybean grown between coconuts has an average height of $70.6 \mathrm{~cm}$, but not significantly different from the height of soybean in open land $(69 \mathrm{~cm})$.

2. The number of soybean branches planted between coconuts is lower (2.1) and significantly different from those planted in open land (5.1).

3. The number of pods planted under the shade of coconut has a lower pod number ( 32 pods) and significantly different from soybeans planted in open land (55 pods).

4. The production of soybean under coconut is lower $(900 \mathrm{~kg} / \mathrm{ha})$ and significantly different from soybean grown in open land $(1,315 \mathrm{~kg} / \mathrm{ha})$.

\section{Suggestion}

Suggestions can be continued with an assessment of shade-tolerant soybean varieties so that they can take advantage of coconut land where the coconut canopy only continues up to $40 \%$ sunlight.

\section{References}

1. A. Handriawan, D.W. Respatie, Tohari, J. Vegetalika 53, 1-14 (2016)

2. A. Marliah, Jurnal Agrista, 161, 1-28 (2012)

3. A. Sutopo. 2019, Jurnal Citra Widya Edukasi, 111, 131-142 (2019)

4. A.Suyantohadi, M. Hariadi, M.H. Purnomo, Jurnal Agritech, 294, 219-227 (2009)

5. Balai Penelitian Tanaman Kacang-Kacangan dan Umbi-Umbian. Deskripsi Varietas Kedelai. http://balitkabi.litbang. deptan.go .id/images/PDF /deskripsi_kedelai. pdf. Diakses pada 28 januari 2017 (2017)

6. B. Liu, C.Wang, YS. Li, J. Jin \& SJ. Herbert, Plant Soil Environment, 568, 384-392 (2010)

7. Chairudin, Efendi \& Sabaruddin, Jurnal Floratek, 10, 26-35 (2015)

8. Elfarisna, Adaptasi Kedelai Terhadap Naungan: Studi Morfologi dan Anatomi. [Thesis] Sekolah Pascasarjana IPB. Bogor (2000)

9. F. Perdana, N. Sutrisna, dan Basuno, Buletin Hasil Kajian, 707, 54-61 (2017)

10. G.E.Nwofia, R.E. Edugbo and E.U.Mbah, J.of agric.Sci., 113, 164-177 (2016)

11.J. Kakiuchi, T. Kobata, Agron J., 96, 398-405 (2004)

12.J.K. Bakhshy, Ghassemi-Golezani, S.Zehtab-Salmasi, and M.Moghaddam, Tech J engine dan App Sci3, 1 39-43 (2013)

13.J. Zhang, D.L. Smith, W. Liu, X. Chen, \& W. Yang, African Journal of Biotechnology 1065, 14392-14398 (2011)

14.K.A. Franklin, New Phytol, 170, 930-944 (2008)

15. K. Katayama, L.U. de la Cruz, S. Sakurai, K. Osumi, JARQ, 32, 139-144 (1998)

16.K.K. Osumi, Kaayama L.U.de Lacruz, and A.C. Luna, Fruit Bearing Behavior of 4 
Legums Cultivated under Shaded Condition. Japan Agricultural Research Quarterly. 32 (2):145-151 (1988)

17.Li, C.Y.Sun, H.Z.Chen, S.Z. Yang, South-west China J of Agric. Sci, 19, 265-269 (2006)

18. L. Mawarni, Jurnal Ilmu Pertanian, 52, 54-59 (2011)

19. M. Afandi, L. Mawarni, Syukri, Jurnal Online Agroekoteknologi, 12, 214-226 (2013)

20. M.H.A Sirait, and A.S. Karyawati, Jurnal Produksi Tanaman, 77, 1304-1313 (2019)

21. M. Oz, A.Karasu, A.T.Goksoy and Z.M.Turan, Internat.J.of Agric. \& Biol., 11, 85-88 (2009)

22. N.Wang, Q. Huang, J. Sun, S. Yan, C. Ding, X. Mei, D. Li, X. Zeng, X. Su, \& Y. Shen, Forest Ecology and Management, 331, 40- 49 (2014)

23. O. Tamungku, A.M. Koleangan, P.C. Wauran, Jurnal Berkala Ilmiah Efisiensi, 92, 152161 (2019).

24.P.M.Perrin, F.J.G.Mitchell. Eur.J. for.res., 132, 218 (2013)

25.R.Y. Wijayati, S. Purwanti, M.M. Adie, Vegetalika, 34, 88 - 97 (2014)

26.S.N. Darwis, Tanaman Sela Di Antara Kelapa. Seri Pengembangan No 2. Pusat Penelitian dan Pengembangan Tanaman Industri. Bogor (1988)

27.S.J. Zhao, Tang, X.Zhao, Y. Feng.C.C. Zhao and M.C. Zhang, Sci. Agric.Sin. 46, 154315 (2013)

28. T. Sundari, G.W.A Susanto., Pen. Pert. Tan. Pangan, 34, 203-2018 (2015)

29. T. Handayani, Pola Pewarisan Sifat Toleran Terhadap Intensitas Cahaya Rendah Pada Kedelai (Glicine Max L Merr) dengan Penciri Spesifik Karakter Anatomi, Morfologi dan Molekuler. Disertasi Program Pasca Sarjana. Intitut Pertanian Bogor (2003)

30. W.Z. Gong, C.D. Jiang, Y.S. Wu, H.H. Chen, W.Y. Liu, \& W.Y. Yang, Phosynthetica. 532, 259-268 (2015)

31.X.Y.Yang, XF.Ye, GS. Liu, HQ. Wei, \& Y. Wang, Chinese Journal of Applied Ecology, 18, 2642-2645 (2007)

32. Y.H.Yan, W.Z. Gong, W.Y. Yang, Y. Wan, XL. Chen, ZQ. Chen, \& LY. Wang, Plant Production Science, 13, $367-374$ (2010) 